\title{
YOGYAKARTA CITY TRANSPORT SERVICE PLANNING FOR INTEGRATION WITH EXISTING TRANSPORT
}

\author{
Siti Malkhamah ${ }^{1 *}$, Almira Pavita Eska ${ }^{1,}$ and Alvian Mustafa ${ }^{1}$ \\ ${ }^{1}$ Department of Civil and Environmental Engineering, \\ Faculty of Engineering, Universitas Gadjah Mada \\ Submitted: 12-04-2018; Revised: 24-08-2018; Accepted: 26-08-2018
}

\begin{abstract}
ABSTRAK
Bus pariwisata dianggap sebagai salah satu penyebab kemacetan di Kota Yogyakarta ketika libur panjang. Penelitian ini dilakukan bertujuan untuk merencanakan angkutan wisata yaitu Trans Jogja Wisata yang terintegrasi dengan angkutan yang ada untuk mengakomodasi wisatawan menuju ke lokasi wisata dari lokasi park and ride. Pengumpulan data dilakukan dengan melakukan survei wawancara pada wisatawan di Tempat Khusus Parkir di Kota Yogyakarta. Data yang dikumpulkan meliputi data tujuan wisata wisatawan, jalan masuk bus pariwisata ke Kota Yogyakarta, dan kondisi lingkungan. Berdasarkan hasil perencanaan Trans Jogja Wisata yang terintegrasi dengan Angkutan yang ada, terdapat 4 trayek yang digunakan untuk mengakomodasi wisatawan untuk berwisata ke Kota Yogyakarta, yaitu Trayek 1, Trayek 2, Trayek 3, dan Trayek 4. Trayek-trayek tersebut terintegrasi dengan angkutan seperti Trans Jogja, becak, andong, serta "si Thole".
\end{abstract}

Kata Kunci: Bus Pariwisata; Integrasi; Trans Jogja Wisata.

\section{ABSTRACT}

The presence of tourist buses is considered to be a factor in Yogyakarta's traffic congestion in long holiday season. Research was conducted to plan a tourism transportation, called Trans Jogja Wisata that is integrated with other public transport services to accommodate tourist movement from park and ride locations to tourist attractions. Data collection was done by carrying out surveys and interviews at a parking location in Yogyakarta. The data collected included tourist destinations, bus gateways to Yogyakarta, and environmental conditions. Based on the analysis results for planning Trans Jogja Wisata's integration with existing public transport, there are four designated routes that can be used to accommodate tourists in getting to their destinations: Route 1, Route 2, Route 3, and Route 4. These routes are fully integrated with the Trans Jogja bus system, becak or pedicabs, andong or horse drawn carriages and Si Thole mini buses.

Keywords: Integration; Tourism Bus; Trans Jogja Wisata.

*Corresponding author: malkhamah@ugm.ac.id

Copyright (C) 2018 THE AUTHOR(S). This article is distributed under a Creative Commons Attribution-Share Alike 4.0 International license. 


\section{INTRODUCTION}

Yogyakarta Special Province (DIY) is a Javanese province famous for its tourism. The city of Yogyakarta is the region most visited by tourists in the province every year. According to the Tourism Office, in 2016 as many as 5,520,952 tourists came to visit the city of Yogyakarta. Travel destinations offered include the Yogyakarta Palace, Malioboro, Beringharjo Market, Vredeburg Fort Museum, Taman Sari, Smart Park, Puro Pakualaman, Gembira Loka Zoo, Kotagede and Yogyakarta Animal and Ornamental Market (PASTY) (Tourism Office of DIY, 2017). Every year during the long holiday, traffic in the city of Yogyakarta becomes denser and causes congestion. One reason for this congestion is the manoeuvres made by the tourist buses when executing u-turns at the entrances and exits of parking areas. This is because the tourist buses often have to stop and wait to be able to perform the manoeuvre (Bappeda Kota Yogyakarta, 2016).

There are several scenarios that can be envisaged to overcome congestion problems during long holidays in Yogyakarta. One of them is the park and ride scenario (Bappeda Kota Yogyakarta, 2016). This scenario does not allow tourist buses to enter and park in the city of Yogyakarta. To ferry tourists to the tourist attractions in the city requires a designated tourist transport. In providing tourist transportation, it is necessary to consider the routes of tourist transport that will serve and integrate with existing modes of transportation so tourists can easily reach their destinations.

The differences between this study and the Bappeda (2016 and 2017) studies are in the route planning and the planned integration details. According to Malkhamah (2014), one important indicators of integration is connectivity and good connectivity means that $75 \%$ of origins and destinations are connected by public transport. Therefore, research has been done to plan tourist transport routes to accommodate tourists from park and ride areas to tourist sites and to integrate these routes with existing transporta- tion modes. The tourist transportation used in this research is Trans Jogja Wisata.

\section{Research Purpose}

The purposes of this research are:

- to plan tourist transport routes to accommodate travellers from park and ride areas to integrated tourist sites,

- to analyze the connectivity by measuring the distribution of tourist destinations by distance,

- to plan the integration of tourist transport with existing modes of transport to improve connectivity.

\section{Literature Review}

In a tourist destination, according to Provincial Regulation DIY No. 1 of 2012, in addition to a tourist attraction, there must also be tourist facilities and accessibility. The direction of tourism transportation accessibility policy includes the development of transportation modes, transportation infrastructure, and transportation systems in supporting tourism development.

According to the Yogyakarta Provincial Regulation No. 4/2010 concerning the Implementation of Tourism, a special business that provides transportation for tourism needs and activities, and which is not regular transport, is called a tourism transportation service business. The business fulfills the purpose of transporting tourists or groups to and from tourist destinations or other places, and provides types of transport which can be either motorized or non-motorized.

Special regular tourism transportation in DIY can be realized to increase tourist visits. The benefits of regular tourism transportation are manifested in increases in tourist numbers, reduction of congestion in tourist areas, reduction of the potential for accidents, savings in travel costs and energy and reductions in pollution (Basuki and Setiadi, 2015).

In the city of Yogyakarta, existing transportation modes include the Trans Jogja bus service, non-motorized vehicles and the tourist transport known as 'si Thole' (minibuses). Trans Jogja is a part of the Bus Rapid Transit 
implementation program launched by the Republic of Indonesia Ministry of Transportation. This system began operations in early March 2008 for the Department of Transportation of DIY. Trans Jogja currently has 105 buses serving 15 routes. There are 113 permanent stops and 90 portable stops.

Non-Motorized Vehicles (NMV) operating in the city of Yogyakarta, among others, are becaks and horse drawn carriages. Development of an ID card for handling tourist transportation in Yogyakarta city based on the National Transportation System includes NMV Abu Bakar Ali pool, NMV Pakualaman pool, NMV Alun-alun Selatan (south square) pool and NMV XT-Square pool. 'si Thole' is a shuttle type transport which uses minibuses with a capacity for 7 passengers. Run with the collaboration of the Government of Yogyakarta City and the Cooperative Forum Communication of Alun-alun Utara (north square) (FCAAU), it was launched on November 25, 2014. This transport operates within a short distance of the Jeron Beteng, or palace area and has two service routes.
Based on Government Regulation no. 742014 for Road Transportation, the criteria of public transportation services for public transport on the routes are as follows:

a. Should have fixed and regular routes,

b. have scheduled, starting, terminating, and embarking and disembarking of passengers in terminals for intercity and state border crossings,

c. should embark and disembark passengers at designated places for rural and urban transport.

In addition, the route network and public motor vehicle needs are prepared based on:

a. spatial layout,

b. the level of demand for freight services,

c. ability to provide transportation services,

d. availability of road and road transport networks,

e. conformity with road class,

f. investment in integration of transport,

g. integration between modes of transport.

Basuki and Malkhamah, 2008 summarize the various measures of urban transport performance as presented in Table 1.

Tabel 1.

Standards of urban transport service

\begin{tabular}{|c|c|c|c|}
\hline \multicolumn{4}{|c|}{ Urban Transport Service Standards from Various Aspects of Interest } \\
\hline Passenger & Operator & Regulator & Non Users \\
\hline $\begin{array}{l}\text { - waiting time } \\
\text { - Walking distance to } \\
\text { bus stop } \\
\text { - Switch between routes } \\
\text { and services } \\
\text { - Travel time } \\
\text { - Travel speed } \\
\text { - Travel financing } \\
\text { - Safety and security } \\
\text { - Reliability } \\
\text { - Range of service } \\
\text { - Information } \\
\text { - Cleanliness } \\
\text { - Service coverage } \\
\text { - Number of services }\end{array}$ & $\begin{array}{l}\text { - Fleet utilization } \\
\text { - Breakdown service } \\
\text { - Fuel consumption } \\
\text { - Accident rate } \\
\text { - Bus condition } \\
\text { - Responsiveness } \\
\text { - Competence } \\
\text { - Courtesy } \\
\text { - Credibility } \\
\text { - Passenger load } \\
\text { - Number of } \\
\text { - complaints } \\
\text { - Comfort } \\
\text { - Speed } \\
\text { - Opage } \\
\text { - Appeating Ratio } \\
\text { transportation } \\
\text { facilities }\end{array}$ & $\begin{array}{l}\text { - Stop facility } \\
\text { - Path } \\
\text { - Ticket system } \\
\text { - Managing organization } \\
\text { - Bus priority applications } \\
\text { - Accessibility } \\
\text { - Ratio of length of city road to } \\
\text { population } \\
\text { - Ratio of vehicle numbers to } \\
\text { number of urban residents } \\
\text { - Ratio between vehicle operating } \\
\text { costs per passenger per km } \\
\text { - Proportion of use of public } \\
\text { transport in urban areas } \\
\text { - Maintenance and construction } \\
\text { - Making law enforcement rules } \\
\text { - Seating capacity per year } \\
\text { - Creation of integrated land } \\
\text { transportation development }\end{array}$ & $\begin{array}{l}\text { - Pollution } \\
\text { - Travel } \\
\text { disturbance } \\
\text { - Congestion } \\
\text { - Accident } \\
\text { rate }\end{array}$ \\
\hline
\end{tabular}

Source: Basuki and Malkhamah, 2008 


\section{Method}

In this research, data retrieval was done in the following way:

1. Interview

Interviews were conducted at 3 locations of tourism bus parking in Yogyakarta City, namely TKP Abu Bakar Ali, Senopati TKP, and Ngabean TKP. Interviews were intended for drivers / tour bus conductors. The number of respondents was 120. At each parking location there was a surveyor interviewing respondents to discover:
a. tour group origin,
b. route taken to enter the city of Yogyakarta,
c. number of buses used to take tour group,
d. time length of tour in Yogyakarta city,
e. tourist attractions visited while in Yogyakarta.

2. Survey of travel time

The travel time survey was conducted by measuring the travel time required to complete 1 route circuit. The vehicle used was set at $30 \mathrm{~km} / \mathrm{h}$ during the trip. Travel time was measured using stopwatch. The time recorded by stopwatch was time of travel. The research by interview survey of respondents took place in 3 locations of tourism bus parking lots and 1 tourist location that provides tourism bus parking, i.e.

a. Special Place Abu Bakar Ali Parking lot;

b. Special Place Senopati Parking;

c. Special Place Ngabean Parking.

Interview data from Gembira Loka Parking used secondary data from the Urban Transportation Study of Yogyakarta City 2016.

3. Data Analysis

The data were then analysed to plan tourist transport routes by taking into account the origin and destination of the travels and the routes taken. The connectivity of the routes were analysed by measuring the walking distance from the nearest bus stops to the tourist destinations. Furthermore bus stops location were planned in such a way that they were integrated with Trans Jogja Wisata, Trans Jogja, no-motorised vehicles and si Thole (the local public transport inside the Beteng Area).

\section{RESULTS AND DISCUSSION Trans Jogja Route Planning of Tours Integrated with Other Transport Based in the Tourist Destination of Yogyakarta City}

In planning a route network for Trans Jogja Wisata, it was necessary to know the locations that have become tourist destinations of choice in the city of Yogyakarta to enable the Trans Jogja Tour route to access these locations. To determine tourist destinations of choice, survey interviews of respondents were conducted in the city of Yogyakarta.

The percentage of tourist destination choice in Yogyakarta City was obtained and is presented in Figure 1.

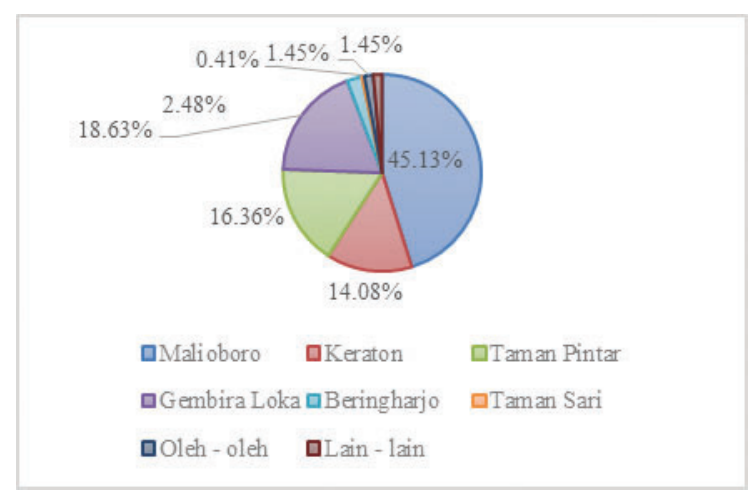

Figure1.

Percentage Chart of Tourist Destinations of Choice

Based on percentage chart in Figure 1, it can be seen that the most popular tourist destination of choice is Malioboro with $45.13 \%$. From the percentage chart in Figure 1 and maps of tourist destinations in Yogyakarta city, a grouping of tourist destinations can be made as is presented in Figure 2. 


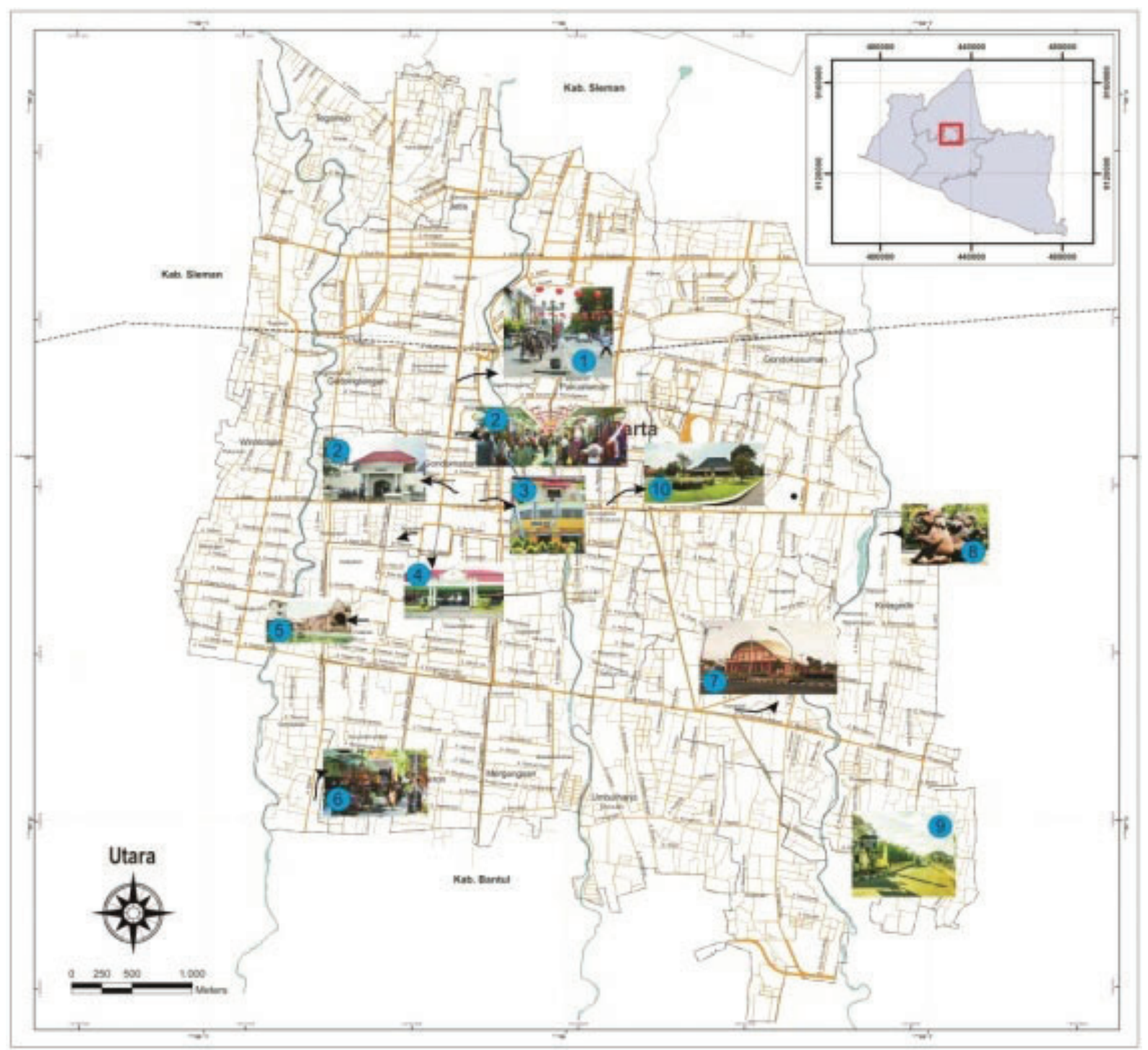

Figure 2.

Grouping of Tour Destinations lows:

The locations listed in Figure 2 are as fol-

1. Malioboro area

2. Beringharjo Market and Vredeburg Fort Museum

3. Smart park

4. The palace area

5. Taman sari

6. PASTY (Animal and Ornamental Market of Yogyakarta)

7. XT-Square

8. Gembira Loka Zoo

9. Kotagede area

10.Puro Pakualaman
Based on the results of the grouping of tourist destinations in Figure 2, a Trans Jogja Wisata route was planned to be integrated with existing transportation modes. Below are integrated Trans Jogja route planning Tours based on each park and ride location:

1. Route 1

Route 1 caters to tourists coming from a park and ride located west of Monjali. The number of bus stops on route 1 is one, this being the Abu Bakar Ali fuel stop. Route 1 is shown in Figure 3. 


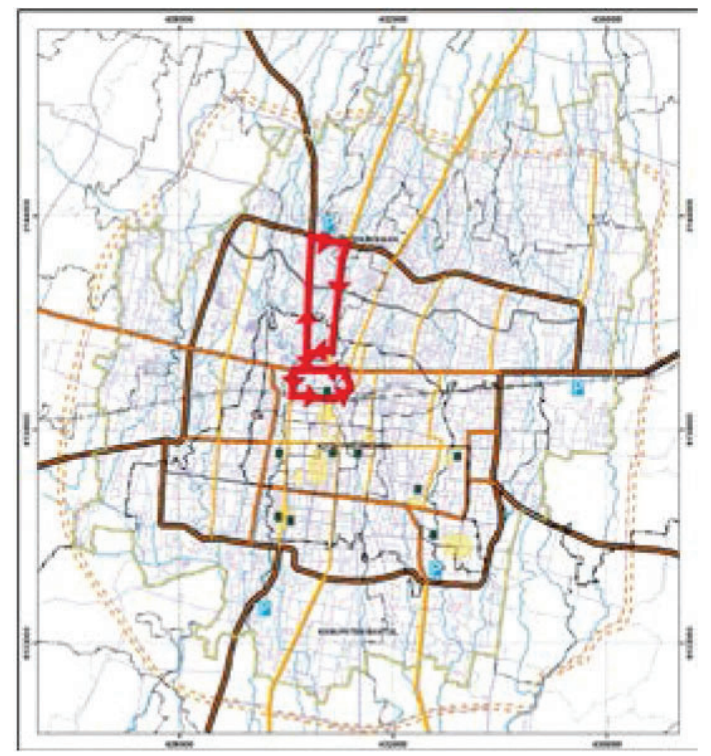

Figure 3.

Route Map 1

\section{Route 2}

Route 2 serves tourists coming from a park and ride located at the Adisucipto Airport Parking lot. Four shelters are available on Route 2, namely the local shelters, Pakualaman shelters, Senopati shelters and Abu Bakar Ali shelters. Route 2 is presented in Figure 4.

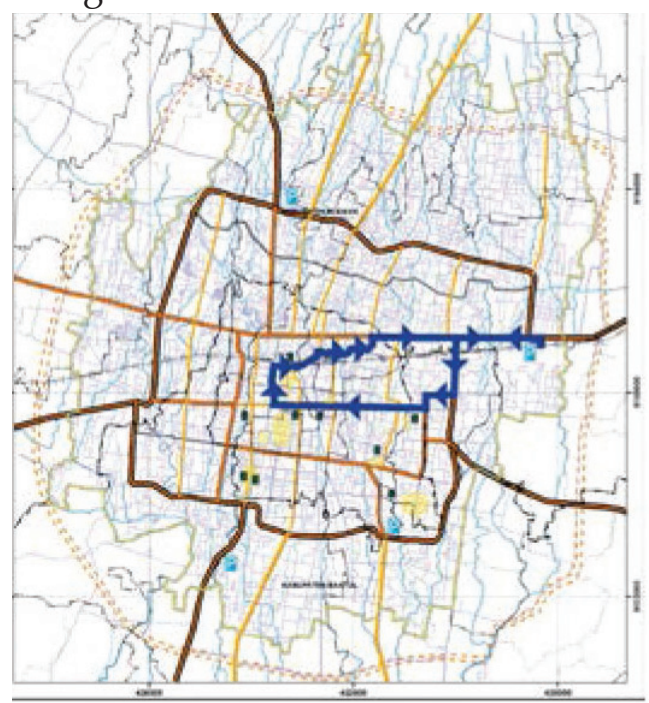

Figure 4.

Route Map 2

3. Route 3

Route 3 serves tourists coming from the park and ride located at Terminal
Giwangan. There are 6 bus stops on Route 3, namely Kotagede shelter, Gembira Loka shelter, Pakualaman shelter, Senopati shelter, Ngabean shelter and XT-Square shelter. Route 3 is shown in Figure 5.

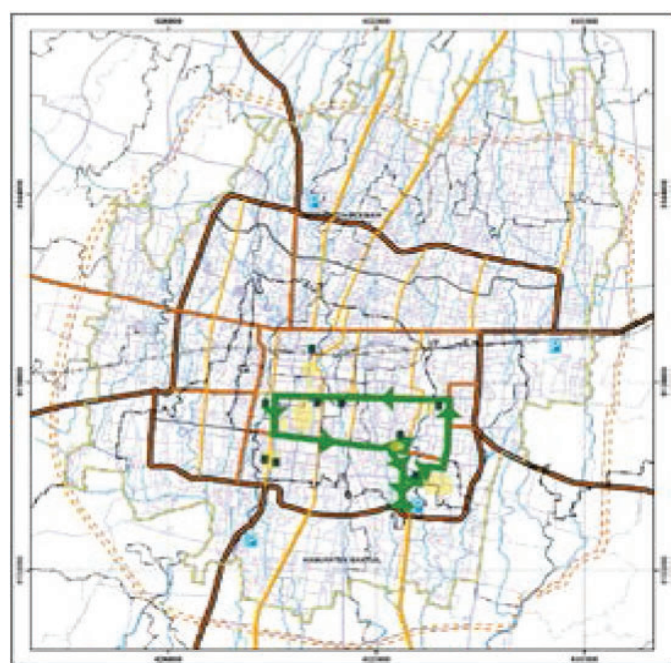

Figure 5.

Route Map 3

4. Route 4

Route 4 caters to tourists coming from a park and ride located in Pasar Niten. The number of bus stops/shelters on Route 4 is 3 pieces, i.e. Pasty shelter 1 , Ngabean shelter and Pasty shelter 2 . Route 4 is shown in Figure 6.

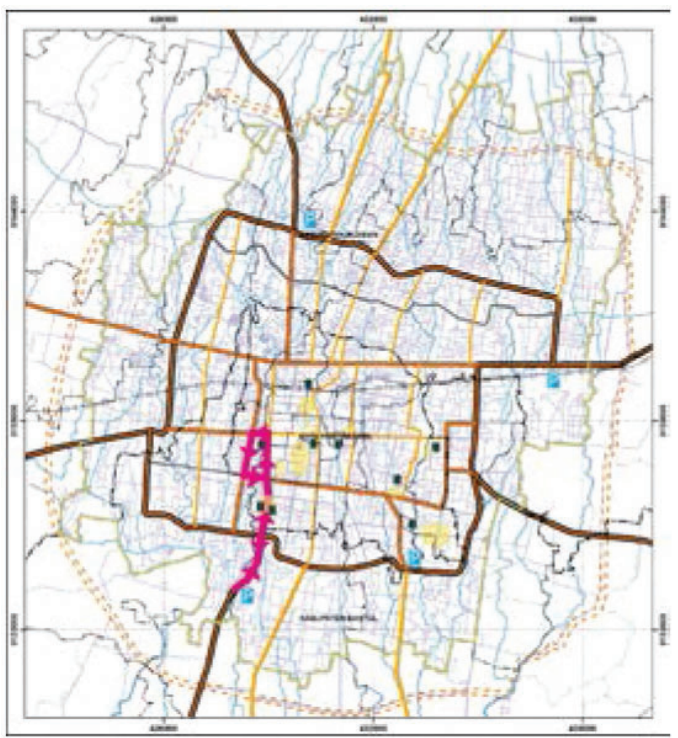

Figure 6.

Route Map 4 


\section{Shown By Walking Distance (Connectivity)}

Basuki and Malkhamah, 2009, used a matrix of the importance of performance method and the impact score method to obtain a priority scale as input for improvements to the urban transport service based on an assessment by urban transportation passengers in Yogyakarta of existing service standards and desired service expectations.

The order of the scale of importance for service performance is different between the two methods. Matrix importance performance method is useful in seeing how far the expec- tations differ from reality that exists, based on assessment by urban transport passengers. So that can be taken as a benchmark in the scale of priority improvement based on service criteria that are still far from the expectations of respondents. The impact score method separates the urban transport respondents who assess the service criteria from their personal experiences, whether they have had problems directly with the criteria of the service assessed. Hence, their judgment will be more profound and more detailed. The following is the order of priority scale of assessment of service criteria presented in Table 2.

Table 2 .

Priority Scale Assessment of Service Criteria

\begin{tabular}{l|l|l}
\multicolumn{2}{c|}{ Importance Analysis - Performance } & \multicolumn{1}{c}{ Impact Score Analysis } \\
\hline \multirow{4}{*}{ Very important } & Safety & Walking distance to the transport stop \\
\cline { 2 - 3 } & Security & Time / length of trip \\
\cline { 2 - 3 } & Punctuality & Timeliness / schedule \\
\cline { 2 - 3 } & Comfort & Lane information, etc. \\
\cline { 2 - 3 } & Information & Comfortable seating in public transport \\
\cline { 2 - 3 } & Cleanliness & Cleanliness of bus stops, vehicles, etc. \\
\cline { 2 - 3 } & Length of Journey & Waiting time at the bus stop \\
\cline { 2 - 3 } & Service Crew & Security of crime \\
\hline \multirow{4}{*}{ Important } & Rates & Convenience at the bus stop \\
\cline { 2 - 3 } & Waiting Time & Hours of service \\
\cline { 2 - 3 } & Service Coverage & Service coverage \\
\cline { 2 - 3 } & Hours of Service & Vehicle crew service \\
\cline { 2 - 3 } & Distance Travelled & Safety \\
\cline { 2 - 3 } & Numbers moved & Substitution between route / vehicle \\
\hline \multirow{2}{*}{ Quite Important } & Ease of ticket purchase & Travel fare \\
\cline { 2 - 3 } & & Ease of getting tickets \\
\hline
\end{tabular}

Source: Basuki and Malkhamah, 2009

From the order of priority scale of assessment of service criteria, the walking distance is a very important priority based on the impact score analysis and it is important based on the analysis of the importance of performance, so that in the Trans Jogja route planning the analysis is also done on the distance analysis. Walking distance is an important indicator of connectivity. Based on the route planning that has been made, an analysis of the walking distance that must be covered by tourists from the bus stop to the tourist destinations to be visited is done. The stop/shelter used as a benchmark for analyzing the walking distance is one that can be reached by Trans Jogja Wisata route (Trans Jogja route integration). One tourist destination can have some walking distance due to different stop/shelter locations depending on the area served by Trans Jogja Wisata route. Below, the results of distance analysis to get to the tourist destinations are presented in Table 3. 
Table 3.

Travel Destination Distribution Based on Walking Distance (Connectivity) *

\begin{tabular}{|c|c|c|c|c|}
\hline No & Walking Distance (m) & Tourist Destination & Halt Stop/Shelter & $\%$ \\
\hline \multirow[t]{4}{*}{1} & \multirow[t]{4}{*}{$0-100$} & Area of Malioboro & Abu Bakar Ali & \multirow[t]{4}{*}{$18 \%$} \\
\hline & & Taman Pintar & Senopati & \\
\hline & & PASTY & PASTY 1, 2 & \\
\hline & & Gembira Loka & Gembira Loka & \\
\hline 2 & $100-200$ & Benteng Vredeburg & Senopati & $5 \%$ \\
\hline \multirow[t]{2}{*}{3} & \multirow[t]{2}{*}{$200-300$} & Beringharjo Market & Senopati & \multirow[t]{2}{*}{$9 \%$} \\
\hline & & XT-Square & XT-Square & \\
\hline 4 & $300-400$ & Puro Pakualaman & Pakualaman & $5 \%$ \\
\hline \multirow[t]{18}{*}{5} & \multirow[t]{18}{*}{$>400$} & Beringharjo Market & \multirow[t]{10}{*}{ Abu Bakar Ali } & \multirow[t]{18}{*}{$64 \%$} \\
\hline & & Vredeburg Fort & & \\
\hline & & Taman Pintar & & \\
\hline & & Kawasan Keraton & & \\
\hline & & Taman Sari & & \\
\hline & & PASTY & & \\
\hline & & XT-Square & & \\
\hline & & Gembira Loka & & \\
\hline & & Kotagede & & \\
\hline & & Puro Pakualaman & & \\
\hline & & Palace Area & Senopati & \\
\hline & & Area of Malioboro & \multirow[t]{6}{*}{ Ngabean } & \\
\hline & & Beringharjo Market & & \\
\hline & & Vredeburg Fort & & \\
\hline & & Taman Pintar & & \\
\hline & & Palace Area & & \\
\hline & & Taman Sari & & \\
\hline & & Kotagede & Kotagede & \\
\hline \multicolumn{4}{|c|}{ Total } & $100 \%$ \\
\hline
\end{tabular}

* description: Good connectivity is measured by a walking distance $\leq 400$ meters

Based on Table 3, it is known that most tourist sites located in Yogyakarta City have to be reached by walking more than $400 \mathrm{~m}$ from the stop. Stops that have a walking distance of more than $400 \mathrm{~m}$ to tourist destinations are Abu Bakar Ali stop/shelter, Senopati shelter, Ngabean stop, and Kotagede shelter.

Based on the Technical Guidance of Places of Public Passenger Vehicle Stops (Department of Transportation, 1996), tourist destinations in Yogyakarta City can be categorized as zone 2 with a maximum stop distance of $300-400 \mathrm{~m}$ so the maximum distance from stop to tourist destination is 400 m. Abu Bakar Ali stop/shelter, Senopati shelter, Ngabean stop/shelter and Kotagede shelter have a walking distance of more than $400 \mathrm{~m}$ to the tourist destinations so that integration is required in addition to integration with Trans Jogja Wisata.

One indicator of the success of DIY transportation (Malkhamah, 2014) is $75 \%$ of tourism activity centers on connection by public transport. By looking at Table 3, this indicator has not been reached, as only $36 \%$ are connected with a walking distance of $\leq$ 400 meters. Therefore integration needs to be done between Trans Jogja Wisata routes. Trans Jogja Wisata integrating with Trans 
Jogja and the integration of Trans Jogja Wisata with Non Motorized Vehicles (KTB) described below.

\section{Planning Trans Jogja Wisata Integration with Existing Modes of Transportation.}

\section{Integration between Trans Jogja Wisata routes}

To be able to reach tourist destinations that cannot be served by one route, the Trans Jogja Wisata route, planning of integration between Trans Jogja Wisata routes is needed. In an integration system between Trans Jogja tourist routes, passengers of Trans Jogja Wisata can switch between routes at bus stops. Below, tourist destinations that require integration between Trans Jogja Wisata routes are presented in Table 4.

Table 4.

Travel Destination and Integration Between Trans Jogja Wisata Routes

\begin{tabular}{l|l|l|l|l|l}
\hline \multirow{2}{*}{ No } & \multirow{2}{*}{ Tourist Destination } & \multirow{2}{*}{ Early Route } & \multicolumn{3}{|c}{ Transit } \\
\cline { 4 - 6 } & & & Stop/Shelter Halt & Route & Destination Halt \\
\hline 1. & PASTY & Route 3 & Ngabean & Route 4 & PASTY 2 \\
\hline 2. & Kotagede & Route 4 & Ngabean & Route 3 & Kotagede \\
\hline 3. & Gembira Loka & Route 4 & Ngabean & Route 3 & Gembira Loka \\
\hline 4. & Pakualaman & Route 4 & Ngabean & Route 3 & Pakualaman \\
\hline
\end{tabular}

Integration of Trans Jogja Wisata with Trans Jogja

If one of the Trans Jogja Tour routes is not integrated directly with other Trans Jogja Tour routes but passes by the Trans Jogja network, integration between Trans Jogja Wisata and Trans Jogja can be planned to go directly to the tourist destination or to the transit stop/halt for the Trans Jogja travel route. Trans Jogja routes that can be integrated with Trans Jogja Tour routes. Trans Jogja routes are paths 1A, 1B, 2A, 2B, 3A, and 3B. Integration that can occur between Trans Jogja Wisata routes and Trans Jogja routes is presented in Table 5.

Table 5.

Integration that can occur between Trans Jogja Wisata Routes and Trans Jogja Routes

\begin{tabular}{l|l|l|l|l|l}
\hline \multirow{2}{*}{ No } & \multirow{2}{*}{ Tourist Destination } & \multirow{2}{*}{ Early Route } & \multicolumn{3}{|c}{ Transit } \\
\cline { 4 - 6 } & & & Transit Halt & \multicolumn{1}{|c}{ Route } & Destination Halt \\
\hline 1. & Gembira Loka & Route1 & Abu Bakar Ali & $\begin{array}{l}\text { Line } \\
1 \mathrm{~A}\end{array}$ & Gedung Juang \\
\hline 2. & Pakualaman & Route 1 & Abu Bakar Ali & $\begin{array}{l}\text { Line } \\
1 \mathrm{~A}\end{array}$ & Pakualaman \\
\hline 3. & Taman Pintar & Route 1 & Abu Bakar Ali & $\begin{array}{l}\text { Line } \\
1 \mathrm{~A}\end{array}$ & Taman Pintar \\
\hline 4. & Kotagede & Route 1 & Abu Bakar Ali & Line 3A & Ngabean \\
\hline 5. & PASTY & Route 1 & Abu Bakar Ali & $\begin{array}{l}\text { Line } \\
3 \mathrm{~A}\end{array}$ & Ngabean \\
\hline 6. & XT-Square & Route 1 & Abu Bakar Ali & Line 3A & Ngabean \\
\hline
\end{tabular}

Integration of Trans Jogja Wisata with Non-Motorized Vehicles (NMV)

To be able to reach tourist destinations that are far from Trans Jogja Wisata stops and tourist destinations that cannot be accessed by Trans Jogja Wisata transportation due to bus restrictions, integration between Trans Jogja Wisata and Non-Motorized Vehicles in 
the form of pedicabs and horse carriges can be planned. In addition, NMV integration can be used to connect between Transit shelters / Trans Jogja shelters where no modes connect both. The location of NMV services is in the area of the Palace, Taman Pintar, Malioboro, Taman Sari, KH Ahmad Dahlan Street, the Flower Market, Pakualaman, XTSquare, Gembira Loka, and Kotagede. For NMV, pools can be built at Ngabean, Alunalun Kidul (South Square), Senopati Area, Abu Bakar Ali, Pakualaman, Gembira Loka, XT-Square, Kotagede.

\section{Integration of Trans Jogja Wisata with "si Thole"}

To be able to reach tourist destinations that cannot be accessed by Trans Jogja Wisata transportation due to buses being prohibited from entering areas such as Jeron Beteng, integration was planned between Trans Jogja Wisata and special transport operated by Jeron Beteng "Thole". The following integration that can occur between Trans Jogja Wisata routes and "si Thole" is presented in Table 6.

Table 6.

Integration between Trans Jogja Tour and "si Thole"

\begin{tabular}{l|l|l|l|l|l}
\hline \multirow{2}{*}{ No } & \multirow{2}{*}{ Tourist Destination } & \multirow{2}{*}{ Early Route } & \multicolumn{3}{|c}{ Transit } \\
\cline { 4 - 5 } & & & Transit Halt & \multicolumn{1}{|c}{ Route } & Thole Halt \\
\hline 1. & Taman Pintar & Route 4 & Ngabean & Thole route 2 & Senopati \\
\hline 2. & Palace Area & Route 2, 3, and 4 & Senopati, Ngabean & Thole route 2 and 1 & Palace \\
\hline 3. & \multirow{2}{*}{ Taman Sari Area } & Route 2, 3 & Senopati & $\begin{array}{l}\text { Thole route 2 } \\
\rightarrow \text { Thole route 1 }\end{array}$ & Taman Sari \\
\cline { 4 - 4 } & & Route 4 & Ngabean & Thole route 1 & \\
\hline
\end{tabular}

\section{Integration between Trans Jogja Wisata, Trans Jogja, and Non Motorized Vehicles}

Based on the route map of Trans Jogja Wisata in Figure 3, a route network has been established to serve the routes. This route network is then integrated with existing transportation modes, namely Trans Jogja, Non-Motorized Vehicles (NMV) in the form of pedicabs and horse carriages and "si Thole". A map of Trans Jogja Wisata integration with existing modes of transportation, as desrcribed above and as presented in Tables 5 and 6 is shown in Figure 7.

\section{CONCLUSION}

Trans Jogja route planning for a network integrated with existed modes of transport is based on tourist destinations of choice according to interviews, the Tourism Destination Guide to Yogyakarta Special Region as well as locations that allow integration. Each park and ride is served by 1 route so there are 4 routes serving Route 1 , Route 2, Route 3 , and Route 4.

The distance analysis is based on a route map of Trans Jogja Wisata. Abu Bakar Ali shelter, Senopati shelter, Ngabean shelter and Kotagede shelter have walking distances of more than $400 \mathrm{~m}$ to the tourist destinations so that integration is required in addition to integration with Trans Jogja Wisata.

The Trans Jogja Wisata route network is integrated with the existing transportation modes of Trans Jogja, Non-Motorized Vehicles (NMV) in the form of pedicabs and horse carriages and "si Thole". Zoning of service area KTB was conducted so as not to impede the flow of other vehicle traffic. This integration is to achieve the connection indicator of $75 \%$ of tourist destinations (connectivity) based on Malkhamah (2014).

Implementation of the planning in this research result is suggested, with continued monitoring and evaluation so that comfortable and affordable travel to tourist destinations can be fulfilled and traffic jams reduced. 


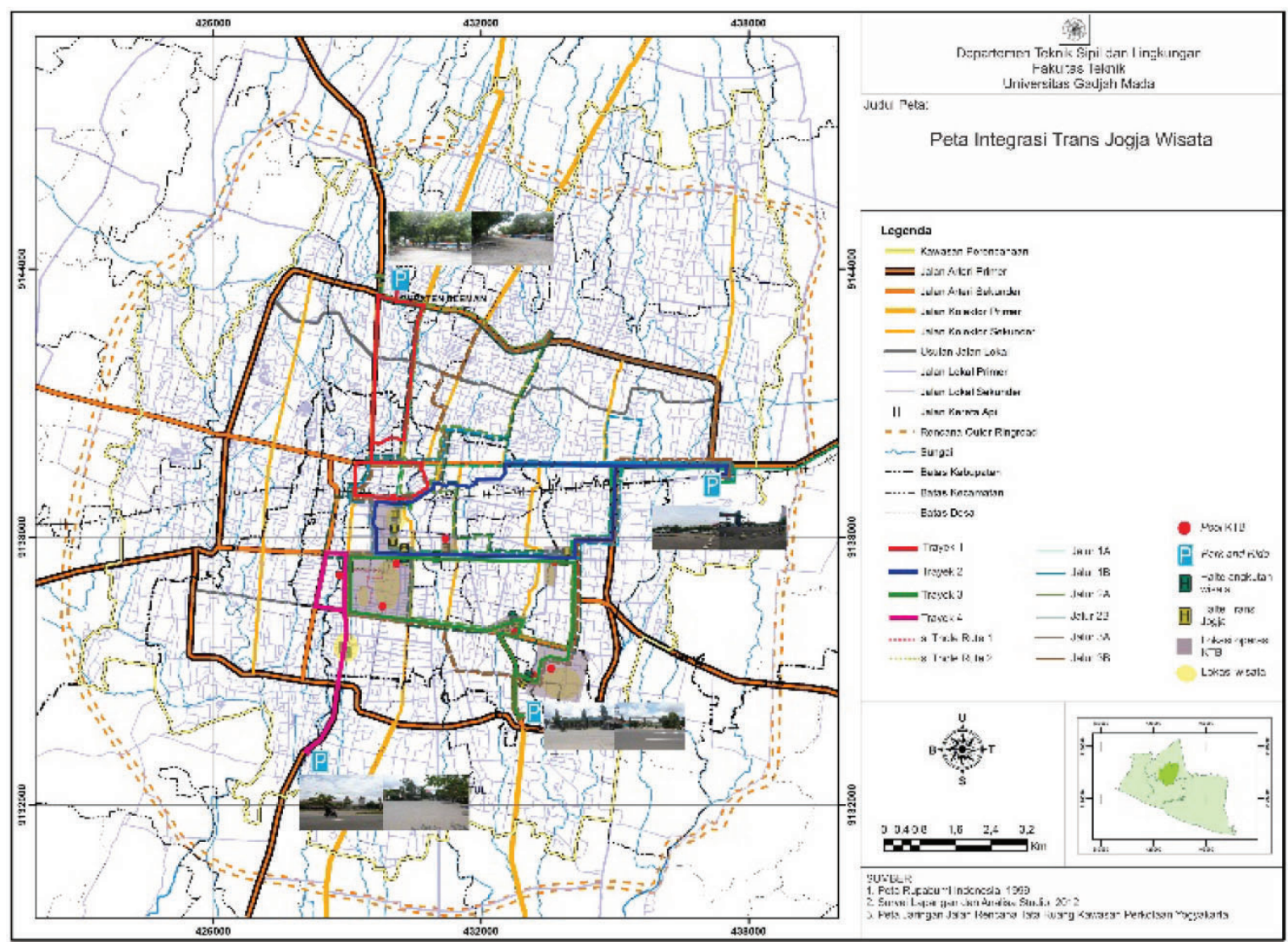

Figure 7. Integration of Trans Jogja Wisata with Existing Modes of Transportation

\section{Acknowledgements}

The author would like to thank the Department of Civil and Environmental Engineering, Faculty of Engineering, Gadjah Mada University (DTSL FT UGM) for financial support given in the form of a DTSL FT UGM Research Grant.

\section{BIBLIOGRAPHY}

Badan Perencanaan Pembangunan Daerah Kota Yogyakarta. 2016. Laporan Akhir Kajian Perencanaan Transportasi Perkotaan Kota Yogyakarta 2016. Tidak Dipublikasikan.

Badan Perencanaan Pembangunan Daerah Kota Yogyakarta. 2017. Masterplan Transportasi Perkotaan. Tidak Dipublikasikan.

Basuki, I. and Setiadi, A. 2015. Potensi Angkutan Umum Pariwisata di
Daerah Istimewa Yogyakarta. Jurnal Transportasi 15(2): 135 - 142.

Basuki, I. and Malkhamah, S. 2009. Penentuan Prioritas Penanganan Kinerja Pelayanan Angkutan Perkotaan. Prosiding Konferensi Nasional Teknik Sipil 3: $17-24$.

Basuki, I. and Malkhamah, S. 2008. Standar Pelayanan Angkutan Perkotaan Indonesia. Prosiding Simposium XI FSTPT, Universitas Diponegoro Semarang: 1 - 9.

Departemen Perhubungan. 1996. Pedoman Teknis Perekayasaan Tempat Perhentian Kendaraan Penumpang Umum. Keputusan Direktur Jenderal Perhubungan Darat Nomor 271/HK.105/ DRJD/96. Direktorat Jenderal Perhubungan Darat. Jakarta. 
Departemen Perhubungan Republik Indonesia. 2002. Pedoman Teknis Penyelenggaraan Angkutan Penumpang Umum di Wilayah Perkotaan Dalam Trayek Tetap dan Teratur. Keputusan Direktur Jenderal Perhubungan Darat Nomor SK.687/AJ.206/ DRJD/2002. Direktorat Jenderal Perhubungan Darat. Jakarta.

Dinas Pariwisata Daerah Istimewa Yogyakarta. 2017. Destinasi Wisata Jogja. Dinas Pariwisata DIY. Yogyakarta.

Dinas Pariwisata Daerah Istimewa Yogyakarta. 2017. Statistik Kepariwisataan 2016. Dinas Pariwisata DIY. Yogyakarta.

Kementerian Perhubungan. 2015. Studi Sistranas Pada Tataran Transportasi Lokal (Tatralok) di Kota Yogyakarta. Sekretariat Badan Penelitian dan Pengembangan Perhubungan. Jakarta.
Malkhamah. 2014. Transportasi sebagai Sumber Permasalahan atau sebagai Motor Penggerak Perekonomian dan Kehidupan Masyarakat. Dalam Bunga Rampai Dewan riset daerah DIY 2014. Pemerintah Daerah Istimewa Yogyakarta dan DRD DIY.

Peraturan Daerah Kota Yogyakarta Nomor 4 Tahun 2010. Penyelenggaraan Kepariwisataan. 2 Juli 2010. Lembaran Daerah Kota Yogyakarta Tahun 2010 Nomor 4. Yogyakarta.

Peraturan Daerah Provinsi Daerah Istimewa Yogyakarta Nomor 1 Tahun 2012. Rencana Induk Pembangunan Kepariwisataan Daerah Provinsi Daerah Istimewa Yogyakarta Tahun 20122025. 14 Maret 2012. Lembaran Daerah Provinsi Daerah Istimewa Yogyakarta Tahun 2012 Nomor 1. Yogyakarta.

Peraturan Pemerintah Republik Indonesia Nomor 74 Tahun 2014. Angkutan Jalan. 14 Oktober 2014. Lembaran Negara Republik Indonesia Tahun 2014 Nomor 260. Jakarta. 